\title{
THE BORDERS OF EUROPE GEOGRPHY AND IMMIGRATION
}

\author{
Thomas Christian HÖRBER*
}

\section{ABSTRACT}

Defining the limits of Europe has always been a contentious issue and the debate over its borders has become more and more heated since the latest enlargement wave of the EU eastwards and the beginning of accession talks with Turkey. The definition of Europe's borders is still an open question shadowed by geographical and cultural cleavages and biases and there seems no cultural consensus across Europe on this critical issue. This essay analyzes the possible definitions of the borders of Europe by giving a particular reference to the problem of (illegal) immigration. In this respect the classical geographic and cultural definitions are discussed respectively and on this basis the author offers in the concluding section some policy solutions to the question of drawing the borderline of Europe in a way that enables the Union to engage in a wellworking relationship with its near abroad, manifest in the rejection of any idea of Fortress Europe and a welcoming immigration policy. In conclusion the essay finds the geographical definition much more applicable and practical in defining the limits of Europe at the expense of the cultural definition despite its some obvious shortcomings.

Key Words: The Borders of Europe, the EU, Geography, Culture, Immigration.

\section{$\ddot{O Z Z T}$}

Avrupa'nın sinırları her zaman için tartışmalı bir mesele olmuştur ve AB'nin son doğuya genişleme dalgası ve Türkiye ile müzakereleri başlatmasından beri konu daha

\footnotetext{
* PhD, MPhil (Cantab), University of Victoria.
} 
da alevlenmiştir. Avrupa'nın sınırlarının tanımlanması coğrafi ve kültürel ayrışma ve önyargıların gölgesinde kalan hâlâ yanıtlanmamış bir soru olarak durmaktadır ve bu konuda Avrupa genelinde bir oydaşmadan söz etmek pek mümkün değildir. Bu makale göç sorunu etrafinda Avrupa'nın sınırlarına ilişkin olası tanımlamaları çözümlemektedir. Bu çerçevede, klasik coğrafi ve kültürel tanımlamalar sirasıyla ele alınmakta ve sonuç bölümünde de Birliğin çevresi ile yakın bir ilişki içine girmesini sağlayacak şekilde kıtanın sınırlarının çizilmesi sorununa ilişkin olarak, Kale Avrupa düşüncesinin reddi ve kucaklayıcı bir gö̧ politikası gibi birtakım somut çözüm önerileri getirilmektedir. Sonuçta, makale, bazl eksik ve kusurlarına rağmen Avrupa'nın sınırlarının belirlenmesi noktasında kültürel tanımlamadan ziyade coğrafi tanımlamayı daha uygulanabilir ve pratik bulmaktadir.

Anahtar Kelimeler: Avrupa'nın sinırları, AB, Coğrafya, Kültür, Göç.

\section{Introduction}

In recent years, the debate concerning the limits of Europe, its borders, has become more and more intense. This development has been fuelled, on the one hand, from within the European Union (EU), by the dynamics of enlargement to the East and, on the other hand, by the pressure from prospective candidate countries to achieve full EU membership in the EU, which has also posed a simple question, 'Where does Europe start, and where does it end?'

Here, of course, one of the most contentious example is Turkey, for two reasons. Firstly, it has been argued that Turkey is not a European country at all, because much the larger part of its land mass is in Asia Minor. Secondly, and more critically, the potential admission of this country has been portrayed as breaching the cultural consensus which underpins Europe ${ }^{1}$ - although an acceptable definition of this cultural consensus has yet to be found.

What the Turkish case shows most clearly is that the idea of Europe is defined along both geographic and cultural cleavages. From the very outset of the European integration process, when it counted only six members, the European dream encompassed far more than the Six, more countries, more of Europe; how much more was left open.

This was not a deliberate policy, rather an accidental merit of the early European integration process, because it was not necessary to define the borders of Europe: the iron curtain stood firmly in the way of any idea of uniting the whole of the continent. When it became, nevertheless, important to define European territorial limits, as in the case of Morocco's application for membership of the European Economic Community (EEC) in the 1960s, a strict geographic interpretation was applied, inevitably excluding France's former protectorate. Another example defies the geographic definition. That is

\footnotetext{
${ }^{1}$ For references see 'III. Cultural definition'.
} 
the Spanish application for EEC membership while still under the Franco dictatorship. This was turned down because of Spain's utter lack of plausible democratic credentials - a genuinely democratic regime had been a sine qua non for EEC members from the outset and became one of the fundamental principles of the cultural definition, i.e. that of Western liberal democracies.

Where lie, then, the limits of the European dream? The explanation has to be far more precise than what Jeremy Rifkin described in his recent book as the 'European dream' and can surely not be defined in opposition to the American dream. In Rifkin's typically bold style, he finishes with: "We Americans used to say that the American dream is worth dying for. The new European dream is worth living for."2 This kind of triteness leads the author to praise the new European dream beyond its merits and brings him to declare the American dream as outmoded and almost no longer worth pursuing. Here, a simplistic approach does little justice to either aspiration.

J. Peter Burgess's edited volume on cultural politics and history from a postmodern perspective is more promising. ${ }^{3}$ He stresses how crucial the debate about European culture and its ingredients is for the survival of the European dream. "When we discover that there are several cultures instead of just one and, consequently, when we acknowledge the end of a sort of cultural monopoly, be it illusory or real, we are threatened with the destruction of our own discovery. Suddenly it becomes possible that there are just others, that we ourselves are an 'other' among others." ${ }^{\text {" }}$ Burgess sees the foundations of European cultural identity in the Renaissance period up to the French Revolution, culminating in the Declaration of the Rights of Man and Citizens in 1789. Although the sections based on the undiscovered spheres of Derrida are more confusing than helpful in that they do not really explain why present Europe cannot be built on past European traditions, i.e. cultural knowledge, there are some more valid points, mainly with regard to the cultural definition of Europe. These will contribute to the findings in the section 'Cultural definition' below.

\section{Research Questions}

The research question of this essay will be focused around possible definitions of the borders of Europe. Hence, the next section will describe the classical geographic definition; the following one the cultural definition of the limits of Europe. Where can the borderlines of Europe be drawn? In the Conclusion this question will be answered and some policies will be suggested in relation with the need to ensure that this

\footnotetext{
${ }^{2}$ Jeremy Rifkin, The European Dream.: How Europe's Vision of the Future is Quietly Eclipsing the American Dream, Penguin, New York, 2004, p. 387.

3 J. Peter Burgess (ed.), Cultural Politics and Political Culture in Postmodern Europe, Postmodern Studies 24, Rodopi, Amsterdam, 1997.

${ }^{4}$ J. Peter Burgess, 'On the Necessity and Impossibility of a European Cultural Identity', in: J. Peter Burgess (ed.), Cultural Politics and Political Culture in Postmodern Europe, quotation from: Paul Ricoeur, History and Truth, p. 19.
} 
borderline does not turn into a moat around a castle, but allow of a well-working neighbouring relationship with the surrounding areas.

\section{Geographic Definition}

Recent assaults on the Spanish enclaves of Ceuta and Melilla - remainders of the Spanish North African Empire - have reminded us that the desperately poor African refugees who tried to storm the Spanish border defences must see Europe as "Fortress Europe". And indeed, from the perspective of European member states on the Mediterranean, this image and the tightening of border controls is not entirely unwanted and has, in recent years, come to reflect an EU policy executed by the member states concerned. There is a real fear of the sheer scale of illegal immigration with all its economic, social and political repercussions. Although European societies around the Mediterranean in particular have always experienced migration, the obvious fear of an invasion of the deprived into Europe, which has itself felt economic pressure in the past decade, has turned into a political motivation for establishing a European migration policy of a kind lending some credence to the unfriendly image of "Fortress Europe".

As legitimate as this policy might be, sensible border controls need the definition of where the border actually is. Despite the relatively obvious answer which every border guard can give, there is also a much more complex, almost philosophical, question as to the limits of the continent. It might be said that geographically these borders have long been defined, along the limits of the European landmass with its islands. Charles de Gaulle's view of European integration, which featured Europe from the Atlantic to the Urals, reflected this definition. ${ }^{5}$

However, European political reality is an entirely different matter, as has been shown in the examples of the Spanish enclaves in North Africa and also the (entirely Spanish) Canary Islands. It is easy to add to this list of exceptions, for example French Guyana, which receives heavy funding from Europe, not least because the European Space Agency's main launch site is situated in this country. This (by location) South American but (in character) Caribbean country is constitutionally 'part of France' as an overseas department (DOM) and therefore EU territory, which begs the question whether the idea of a geographic definition of Europe's borders is still valid.

It might be argued that Morocco's membership application was rejected in the early days of European integration on the very grounds that Morocco could not be defined geographically as a European state. This is the definition which is still applied by EU member states in the Mediterranean.

However, in the future and in another theatre such a call might not be as easy. With Eastern enlargement, the EU is rapidly approaching its geographic continental limits on the European mainland. Faced with a candidacy of Turkey, the EU, for the

\footnotetext{
${ }^{5}$ E. Roussel, De Gaulle, nrf Gallimard, Paris, 2002, p. 806, 807, 810.
} 
first time, now considers bringing in a state almost all of which is in Asia Minor, with borders with countries of the Middle East. This is only the latest instance where the geographic definition of Europe has to be fudged, if it is still applied. ${ }^{6}$ Regardless of how the decision on Turkey will turn out, the EU will have to face similar questions in the continuation of Eastern enlargement. Inevitably, there will be future member states partially in geographic Europe and partially out - the past application of Russia for EU membership is only the most striking example. If the purely geographic definition is maintained, the EU governments will have to make up their minds whether these potential future member states have a genuinely European vocation, justifying eligibility for EU membership. Alternatively, other criteria will have to be applied to determine eligibility.

In conclusion, a purely geographic definition of Europe's borders seems neither to reflect reality nor to be a sensible way of attempting to determine where Europe starts and where it finishes.

The cultural definition of Europe is the obvious alternative.

\section{Cultural Definition}

The problem with the cultural definition of Europe is that it is, by its very nature, more complex than a line on the map. The borderlines become blurred by history, politics, ethnicity and past migration, to name only the most obvious influences. A good example of an attempt to establish a cultural definition of Europe is Trond Berg Eriksen's essay on "The European Self-Image" Unfortunately, Eriksen tries to span the historical arch a bit too far. His starting point is the establishment of the Holy Roman Empire by the Franks in the early $8^{\text {th }}$ century. He stresses the Christian faith as an important element of European internal unity. This justifies so early a start in European history. It opens up the debate concerning the role of religion as a defining factor in modern societies. Christianity can, hence, be seen as one of the core elements of European identity: the present composition of the EU seems to support this picture that Christianity has traditionally been a unifying factor in European self-identity and still has a considerable impact on today's European societies. ${ }^{8}$ This has been put forward as one of the reasons for the reticence as regards full membership for Turkey, which in this

\footnotetext{
${ }^{6}$ For a politically and academically sound contribution to the debate about future membership of Turkey in the EU, see Rainer Hermann, 'Die Türkei - ein Teil der Europäischen Union?', in: Diether Döring, Eduard J.M. Kroker (ed.), Europa und der Islam, Königsteiner Forum 2004, Societätsverlag, Frankfurt a.M., 2006, pp. 217-240

${ }^{7}$ Trond Berg Eriksen, "The European Self-Image" in: J. Peter Burgess (ed.), Cultural Politics and Political Culture in Postmodern Europe, p. 111-117

${ }^{8}$ Iver B. Neumann and Jennifer M. Welsh, "'The Turk"' as Europe's Other', in: J. Peter Burgess (ed.), Cultural Politics and Political Culture in Postmodern Europe, p. 294.
} 
definition could not count as European because of its predominantly Muslim population.

Alternatively, religion could reasonably be dismissed as an outmoded parameter of identity formation. It used to be a valid way of looking at community-building and composure in the past, but is no longer appropriate in our present, heavily secularized, times.

Indeed, the ideal of secular states in Europe may serve as example, as implemented in France from the French Revolution; or Bismarck's rejection of papal authority in the Kulturkampf; and even Britain's multi-religious Empire. The secular state was also realised in the reformation of the Ottoman Empire into modern Turkey under Atatürk. ${ }^{10}$ Hence, in terms of this leading European ideal of the humanist brand, Turkey would rank for membership of the European collectivity. Eriksen rightly concludes that European identity has components of both - the religious and the humanist definition. The really interesting observation is that identity definition seems to involve the definition of an Other. It is the mechanism which makes differences to other groups, rather than other individuals, unacceptable. Religion has historically been used very often as a marker of the Other. And in the debate about European identity, the contemporary version of the Other could be just a variation of this old phenomenon of discrimination. What makes this element intriguing in the process of European enlargement is that neither the Us, i.e. the current EU member-states, nor the Other is clearly defined, because new member states have joined and more will join in the near future, as Eriksen correctly points out. "Now that we have immigrants from all over the world, we nearly consider Italians and Spaniards to be Scandinavians!" 11 Hence, Eastern enlargement has a direct impact on the definition of European identity and changes it with every new member-state. Religion is, therefore, only one component in the definition of the Other and in the definition of European identity. Arguably, it is a component whose influence is more and more reduced, because the tide of faith has receded so far in all present members and potential candidates to the EU. Eriksen suggests that difference in religion is merely a symptom of the long-standing tradition of a divided East and West. His earliest source is Homer's Iliad and Odyssey from Greece of the $2^{\text {nd }}$ millennium B.C. and Virgil's Aeneid from Imperial Rome. Again, the criticism must be made that these sources may be one or two chronological steps too far back, even if Eriksen seeks only to bring out underlying trends in European culture. The most obvious objection is that the ancient authors definitely did not write with the intention of explaining Europe, certainly not as we know it nowadays. Our Europe is a

\footnotetext{
${ }^{9}$ For the contentious issue of the impact of Islam on Europe, its core credentials and the problems a predominantly Muslim state might have to face in the predominantly Christian EU, see Tilman Nagel, 'Die 1400jährigen Geschichte des Islams' and Hamideh Mohagheghi, 'Rolle der Frauen im Islam'. The contribution of Hans-Peter Raddatz, 'Allahs Gesetz im Westen' should be read with caution, because of a clear adherence to Samuel Huntington's Clash of Civilisations ideas. All three papers in: Diether Döring, Eduard J.M. Kroker (Hrsg.), Europa und der Islam, p. 39, $59,99,149$. It should be noted that while democratic government is a membership requirement stipulated in the EEC Treaty, there is no such reference to religion.
} 
later concept. Homer and Virgil were concerned with ancient Greece and the Roman Empire, respectively, certainly not with Eastern Europe. This brings out the most critical element in Eriksen's argument, namely that there is a classical dividing line between East and West which can be traced from the ancient past to our time. The danger in such a "historical truth" is oversimplification, which leads to distortions like the often invoked 'fact' that the ancient borders of the Holy Roman Empire and the Eastern Roman Empire and later the Ottoman Empire match quite closely the borders of the EU - the exclusion of Turkey being explicit in this construct.

The point which must be made here is that superficial similarities between ancient and modern borders are just that and nothing more. Therefore, the East-West division which can be found in classical sources has to be seen in the context of the time, just like modern frontiers, if we are to arrive at a historically valid, in the sense of useful, analysis and not just discriminatory polemic.

Another good example of misrepresentation which results from oversimplification is Eriksen's claim that:

The Greeks' [as the ancient Westerners] battles against the Persian king [the East] were a conflict between Asia and Europe, despotism and freedom, dictatorship and law, barbarians and the Greeks, offensive and defensive wars, arrogance and piety. ${ }^{12}$

To speak only from a Greek perspective, because these are the only surviving sources, the Persian wars were not battles against Asia; the concept did not yet exist, nor was the continent explored until Alexander the Great in the $2^{\text {nd }}$ century B.C., which is some 400 to 500 years after the Persian wars. Furthermore, vast areas of Asia Minor were an integral part of Greek territory, mainly along the coast line, which means that an ideological division between Europe and Asia is not very likely to be found in Greek minds. On the contrary, classical trading Empires, e.g. Athens, depended on sea communication between Greek poleis and what we consider nowadays as Asia, for example, which seems to be more of a unifying factor between the two.

Importantly, Aristotle speaks of an almost ideological fight against the Persians, but not in terms of a divide between Asia and Europe, but between barbarians and Greeks, as Eriksen rightly points out. This is the dividing line in Greek/Aristotelian ideology between humans - Greeks, and wild beasts - Persians. This is the most important divide and can only be understood on the basis of Aristotle's philosophy, where the Greek polis, the city-state, is defined as the highest form of human life in society and the only way of being truly human. No word of a territorial divide between Asia and Europe. Here we have a clear illustration of the importance of a thorough use

\footnotetext{
${ }^{10}$ Iver B. Neumann and Jennifer M. Welsh, "The Turk" as Europe's Other, p. 291-316, This essay analyses the historical relations between the Ottoman Empire and European states and goes on to compare these relations with today's relationship with Turkey.

${ }^{11}$ Trond Berg Eriksen, "The European Self-Image", p. 112.

${ }^{12}$ Ibid., p. 113.
} 
of historical sources, which Eriksen unfortunately neglects. The undue simplification and unhelpful distortion of history is summed up in the following quotation:

I have often wondered why the distinction between North and South in Europe has become less important than that between East and West. The answer is indeed that the Reformation, which created the distinction between North and South, took place 1,000 years later than the cultural distinction which was organized with Emperor Diocletian's tetrarch (290 A.D.) and which developed into a division between Eastern and Western Europe. $^{13}$

The real danger is that such arguments may be used to lend academic respectability and, hence, authority to policies of exclusion. Fortunately, Eriksen makes up for historical inaccuracies with a nice historical appeal which advocates a constructive political approach:

Mind you, the institutions influenced the definitions. NATO advanced one Western self-image; The E.U. circulates another. The point is that there isn't any pure and worthy idea of Europe which can be sold in political institutions. The arrangements themselves contribute to deciding the extent and the content of the ideas. History does not provide Europe's just and natural border, since self-understanding is always mediated by identity-creating events and institutions. This doesn't mean everything is possible at all times or for all people, but it implies that we as political actors are responsible for the self-image which justifies initiatives toward recognizing similarities and differences. $^{14}$

The appropriate use of ancient sources and a good understanding of hermeneutics in Hans-Georg Gadamer's essay on the humanist foundations of Europe offer an enlightening contrast to Eriksen. In 'Europe's plurality past and future'15 Gadamer conducts a tour d'horizon through European history and its heritage. It is a deeply philosophical essay which begins with Aristotle's Metaphysics and moves smoothly on to an explanation of $20^{\text {th }}$ century ideology. Aristotle's order for the world was based on equals. The whole universe could be understood on this basis. That was why the stars were in the sky among equals; that was why the stone fell to the ground, that is to its equals and that was why Athenians lived together. Modern science - from the age of Enlightenment of the $17^{\text {th }}$ century - did away with all this tangible equality and sought to place the world on a rational basis. What we lost through rationalisation was a general explanation of the order of the world. The explanation became too complex to be understood by everyone. However, the human search for a sense of his life was still a basic need of everyone which was satisfied by ideology in the $19^{\text {th }}$ and $20^{\text {th }}$ centuries. Earlier, it had been satisfied by religion, but not convincingly enough and in the age of

\footnotetext{
${ }^{13}$ Ibid., p. 114.

${ }^{14}$ Ibid., p. 116.

${ }^{15}$ H.-G. Gadamer, "Die Vielfalt Europas Erbe und Zukunft", in: H.-G. Gadamer, Das Erbe Europas, Suhrkamp, Frankfurt, 1989, p. 7-34
} 
logic the shortcomings of faith became too obvious to be ignored. Faith was no longer a comprehensive and satisfactory explanation. Ideology was therefore the human answer to the human need for a purpose. Expansion of knowledge became the path to comprehensive understanding and hence an answer to the question as to the purpose of life. Gadamer sees the drive for knowledge, scientific culture and also all ideologies as inherently European. It is indeed a hallmark not just of European, but of Western societies. As a cultural definition of the limits of Europe this leads us far beyond the geographic borders of Europe. There is hardly a corner of this planet where knowledgebased societies do not prevail and where these societies do not depend to some extent on societal logic which can be characterised as ideology, North America and Australia being only the most striking examples and also the ones which are geographically the most remote from Europe. Hence, Gadamer's definition of core European characteristics provides another possibility for the definition of Europe and thus casts even more doubt upon the viability of the geographic definition of the continent.

Peter Normann Waage ${ }^{16}$ makes the same historical mistake as Eriksen: "The EU bears a remarkable resemblance to the pagan Roman Empire." This is a generalisation so broad that it cannot possibly be true in the sense that it enhances our historical understanding of either the past or the present. What is, however, interesting, is that Waage attributes 'ideal' to the East and 'reality' to West. The 'ideal' is the emphasis on the godly nature of Christ in the Orthodox Church. This led later to the fight for a better (ideal) world in the Communist society - the idealist spark in Communist ideology being deliberately emphasised in this analysis, rather than the totalitarian elements. In Western ideology, 'reality' is embodied in human Jesus, real benefits in Capitalism and material Realpolitik. These, too, are very wide arches, but what makes this essay better than Eriksen's is the restraint the author shows in the points he makes. His emphasis on Eastern Socialist tradition culminates in his - valid - claim that there are many parallels between mediaeval Byzantine and modern Russian society and that this past is an integral part of the explanation as to why the Soviet system took hold so firmly and for so long in Russia. These are parallels often overlooked against the background of Lenin proclaiming revolution against the old regime. It seems a reasonable contention that, in fact, even the quite bold Communist vision of a new society was heavily influenced by well-entrenched past traditions. The idealism and the mass support in the early years of the revolution can be seen in this light. In terms of the cultural definition of European identity, the Cold War divide, which, until recently, moulded European mindsets, is a much more convincing dividing line for European identity, regardless of whether this can be traced back to orthodox tradition. In order to understand why former Eastern bloc countries and even the Soviet Union applied for EU membership despite the existing cultural divide between East and West, a brief excursion into the concept of antagonism might be helpful.

\footnotetext{
${ }^{16}$ Peter Normann Waage, "The Division and Integration of Europe", in: J. Peter Burgess (ed.), Cultural Politics and Political Culture in Postmodern Europe, p. 155-167.
} 
In his Discourse Theory and Political Analysis ${ }^{17}$ David Howarth condensed Ernesto Laclau's and Chantal Mouffe's idea of antagonism. His main thesis is that social antagonism generates identity. A refinement of this can be seen in the concept of 'Historical Antagonism', which is the opposition to previous regimes or preceding generations. ${ }^{18}$ One could also call it the 'Never Again Effect', meaning the desideratum that politically or historically disastrous mistakes attributed to the previous generation should not be allowed to recur. A good example of this general rejection of past approaches can be seen in the post-1945 reaction in Germany to inter-war politics (1919-1939), the consequence of which was perceived as being the outbreak of World War II. Historical Antagonism, therefore, accounts for a loss of credibility of a political method or of a whole political system and certainly for the dismay felt by the post-war generation at the repercussion of such action on their lives.

In the East European context this can explain the peaceful revolutions against Communist regimes. More generally, the cry for freedom which rang throughout Communist Eastern Europe from 1989 can be seen as a revolution against the past rigidity of the political and social system. The peoples of Eastern Europe claimed the right to shape the societies they lived in, not least on the basis of opposition to the previous Communist way of life, i.e. historical antagonism. The consequence of such historical antagonism can be seen in their decisions to sign up to the European idea, which, as another facet of the political antagonism of the Cold War period, stood for values diametrically opposed to those of Communist regimes, e.g. democracy, property and fundamental freedoms.

Hence, historical antagonism can explain why former Communist Eastern European countries executed a complete regime change, and sought EU membership and thus made a major step on the road of reintroducing core European values into their societies, which broke free from suppression in the relatively bloodless revolutions of 1989/90. These revolutions and the later institutional consolidation wrought by the absorption of central and Eastern European countries into European organisations, such as NATO and the EU, is the strongest affirmation of European cultural identity yet.

In European history of the past centuries, it has been the nation state which defined borderlines and hence the nation state is another possible cultural definition. Jean-Marie Guéhenno gives a very interesting definition of the nation state in his essay on the end of the nation. ${ }^{19}$

${ }^{17}$ David Howarth (ed.), Discourse Theory and Political Analysis: Identities, Hegemonies and Social Change, MUP, Manchester, 2000.

${ }^{18}$ See Thomas Hörber, The Foundations of Europe - European Integration Ideas in France, Germany and Britain in the 1950s, VS-Verlag, Wiesbaden, 2006, p. 325.

19 Jean-Marie Guéhenno, "The end of the nation", in: J. Peter Burgess (ed.), Cultural Politics and Political Culture in Postmodern Europe, p. 367-379. Ulla Holm also provides a definition of the nation states along the lines of providing cultural identity in Europe, see, Ulla Holm, "The Struggle between the Political Nation and the Cultural Nation", in: J. Peter Burgess (ed.), Cultural Politics and Political Culture in Postmodern Europe, p. 395-414. 
A nation defines itself first by what it is not: it is not a social group, it is not a religious group, and it is not a racial group; in other words, what binds together the citizens of a nation is the product of a unique combination of historical factors, and can never be reduced to a single dimension, whether social, religious or racial. What distinguishes a national community, as the Europeans have defined it, from all other communities lies in this: it brings people together not for what they are but for the memory of what they have been. A nation has no other definition but historical. It is the locus of a common history, of common misfortunes, and of common triumphs. It is the locus of a shared destiny. But a nation cannot be defined only by a single affiliation: if that were the case, it would be no more than an extended tribe. A nation, in the European definition of the word, is first of all a place, that is to say, a territory defined by precise frontiers, as precise as the boundaries that mark the limits of the fields in the old countryside of Europe. ${ }^{20}$

The author claims that global problems blur national frontiers more and more so that the territorial dimension of the nation state becomes less binding. Citizens' loyalty towards soil is slowly being replaced by loyalty towards networks through which the identification process of the future will work. ${ }^{21}$ One answer to global challenges and the fading identification with the "fatherland" is offered by political constructs encompassing larger areas than the original nation state, such as the EU. However, this does not automatically mean that the nation state as such is disappearing, as Guéhenno suggests. Still, another indication that the EU is taking over classical functions of the nation state can be seen in the very question of this paper. It is no longer the borders of France, of Germany or any other European nation state, the more relevant question now is 'Where are the borders of Europe'.

In conclusion, the cultural definition of Europe is complex and has relevance at many different levels, so that it is really not easy to find a definition that can be of general applicability. Usually any helpful cultural definition of Europe involves several components of cultural definitions; a diversity which makes a consensus- based cultural definition in politics very difficult. Again, the example of Turkey shows that even within the field of cultural definitions, one can be used against another and hence the application of a cultural definition of Europe seems difficult to apply in similarly complex political environments such as Eastern enlargement.

\section{Conclusion}

In the last wave of Eastern enlargement, which added ten Central and East European countries to the Union, the Fifteen (current member states) agreed, fearing excessive waves of immigration, to temporary restrictions on one of the four basic EU freedoms, e.g. freedom of movement of workers. Apart from an understandable need to cushion the impact of so many new arrivals on national labour markets and social

\footnotetext{
${ }^{20}$ Jean-Marie Guéhenno, 'The end of the nation', p. 370.

${ }^{21}$ Ibid.,
} 
security systems, these restrictions also serve to appease persisting nationalistic sentiment in host countries. On their side, the accession candidates - Poland is a prime example - negotiated restrictions on the freedom of movement of capital and the right of establishment. Considerable limitations on foreigners' ability to acquire assets, notably land, in the accession states will remain in force for some time to come. Fears of being bought out by foreigners, but also of restitution claims by Germans expelled after the war, impelled the Polish and Czech governments to insist on these clauses; ${ }^{22}$ in the same way as in the old EU countries, these political precautions have been designed to mollify nationalistic opponents to enlargement. As in past enlargement rounds, transition periods have been established as the prime tool for the necessary adaptation between old and new member states. The question remains as to where is the limit at which adaptation is no longer possible? Where are the borders where cultural difference can no longer be bridged? If the cultural definition is applied, there is no limit, because adaptation is always possible, if time is an unlimited resource and both sides are willing. The cultural definitions of Europe are, therefore, perfect as an ideal for peaceful coexistence of mankind, not just Europeans. However, as a concrete guideline for politics, such definitions are unworkable within a reasonably limited timeframe and, in particular, with more candidates for EU enlargement in the waiting.

Hence, the geographic definition of Europe is still the only viable policy which can readily be applied. Beyond practicability, one might also invoke Fernand Braudel as a philosophical exponent whose work supports such a definition for Europe. He falls into the broader class of French Annales historians. ${ }^{23}$ His core observation is that large structures like geographical environment influence the behaviour of historical agents at least as much as historical events or human relations. With his masterpiece, The Mediterranean and the Mediterranean World in the Age of Philipp II, Fernand Braudel ranks as the most fervent advocate of this thesis. His achievement is to trace the actual conduct of a Spanish king back to long-standing traditions and the even more profound influence of Spanish geography on Spanish policies, such as the fact that the Pyrenees, hindering expansion into continental Europe, served, following the expulsion of the Moors, to favour the development of the first colonial Empire.

Despite the perception that geography is the only workable definition of Europe, old ideas such as Europe from the Atlantic to the Urals, referred to above, need refinement, because such a definition of Europe clearly conflicts with presently established political borders in Europe, e.g. Russia. The harsh break-off on the geographic borders of Europe has to be smoothed out to account for or accommodate countries which straddle the borderlines and to extend a welcoming hand to Europe's neighbours.

\footnotetext{
${ }^{22}$ Steve Wood, Germany and East-Central Europe - Political, Economic and Socio-Cultural Relations in the Era of EU Enlargement, Ashgate, Aldershot, 2004, p. 29, 42.

${ }^{23}$ See Stuart Clark, "The Annales historians", in: Q. Skinner (ed.), The Return of Grand Theory in the Human Sciences, CUP, 1985.
} 
As shown in previous rounds of enlargement, in particular in Central and Eastern Europe, preparatory steps for future enlargement - the PHARE programme being one of the most successful examples - have generally been well received by applicant countries and must be seen as mutually beneficial. The EU has shown "(...) what outsiders [the EU] can offer to help foreign societies reform." ${ }^{24}$ The extension of stability - arguably the most important achievement of the European integration process - into neighbouring areas must be seen as a normatively positive EU policy and, indeed, something most welcomed by areas along the geographic borderlines of Europe. ${ }^{25}$ Hence, the EU has gathered expertise to act as a stabilising influence along its geographic borders and should use this expertise to further develop active neighbourhood policies which include, if not admit, adjacent countries into the European community. Once enlargement has reached the geographic limits of Europe proper, it will be almost inevitable that the case for each further applicant which is territorially only partially in Europe will be considered on its individual merits by the responsible EU institutions. This is a political process in which the EU has also acquired substantial expertise in past enlargement rounds - the key references will be the Acquis communautaire and the Copenhagen criteria.

Hence, the political tools are in place to settle the questions as to the final territorial composition of 'Europe'. Once this is finished, it might be time to look beyond concrete matters of territory. It has been noted in this paper that the EU has significant territorial enclaves outside the continent itself. The remainders of several European colonial empires, such as those in North Africa, remind us that Europe's borderlines have not necessarily been drawn by reason, but rather by history, custom, practice, even mere accident. Once the internal territorial consolidation of Europe is finished, it might be time to dispose once and for all of necessarily artificial arguments about Europe's borders and apply one of the most persuasive lessons of European integration, that of the need to overcome borders, to reach out beyond the rigidities of our own mindset and find common ground with peoples beyond our borders. In a concrete way that will mean that the still deeply engrained reflex in Europe of shutting national societies off from immigration will have to be tackled. Let us hope that the other lesson and indeed the achievement of the European integration venture - that coming together means peace and prosperity - can be extended beyond the European continent and let us hope that Europe can lend a helping hand - not more, excluding any idea of a revival of European imperialism - in this achievement. For Europe that will mean that it will have to work on a more positive immigration policy over the next decades. Despite substantial differences in nature and needs, US American immigration

\footnotetext{
${ }^{24}$ Wade Jacoby, The Enlargement of the European Union and NATO - Ordering from the Menu in Central Europe, CUP Cambridge, 2004, p. 118. For similar contributions, see Roland Sturm/Heinrich Pehle (Hg.): Die neue Europäische Union: Die Osterweiterung und ihre Folgen. Opladen: Verlag Barbara Budrich 2006, in particular Stefan Fröhlich, "Auswirkungen der Osterweiterung auf die GASP und NATO".

25 See Petra Schaser, "Die Kontrolle der Außengrenzen der EU - vor und nach der Osterweiterung", in: Roland Sturm/Heinrich Pehle (Hg.): Die neue Europäische Union: Die Osterweiterung und ihre Folgen, p. 165.
} 
policy might become a guiding example. In Europe the sheer vitalising beauty of a multicultural society has received too little recognition - certainly not to the extent that it can be turned into a workable policy with widespread public support, soon. On the contrary, the US realised the power of hope and economic potential of a positive immigration policy. Nothing else could convey better the meaning of a warm welcome than the credo of the Statue of Liberty,

Give me your tired, your poor,

Your huddled masses yearning to breathe free,

The wretched refuse of your teeming shore...

In Europe, too, we have to reassert our rejection of any idea of a Fortress Europe and hence a welcoming immigration policy is long overdue, as another component of a positive policy of openness and outreach. 